Izvirni znanstveni članek / Original scientific article

\title{
Prilagoditev in psihometrična validacija Lestvice profesionalnih kompetenc medicinskih sester v izrednih razmerah v času epidemije SARS-CoV-2 (COVID-19) v Sloveniji
}

\author{
Adaptation and psychometric validation of the Disaster Nursing Core Competencies \\ Scale during the time of the SARS-CoV-2 (COVID-19) epidemic in Slovenia
}

\author{
Mirko Prosen ${ }^{1, *}$, Sabina Ličen ${ }^{1}$, Igor Karnjuš ${ }^{1}$
}

Ključne besede: zdravstvena nega; množične nesreče; zaščita in reševanje; javno zdravje;

koronavirusna bolezen

Key words: nursing; mass accident; civil protection and disaster relief; public health; coronavirus disease

${ }^{1}$ Univerza na Primorskem, Fakulteta za vede o zdravju, Katedra za zdravstveno nego, Polje 42, 6310 Izola, Slovenija

"Korespondenčni avtor/ Corresponding author: mirko.prosen@fvz.upr.si

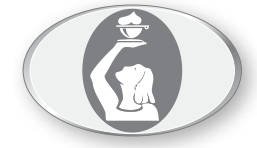

Prejeto / Received: 10. 5. 2020

Sprejeto / Accepted: 28. 5. 2020

\section{IZVLEČEK}

Uvod: Za uspešno, samozavestno in učinkovito spoprijemanje s spremenjenimi vlogami in zagotavljanje ustrezne pomoči prizadetim morajo biti tudi medicinske sestre $\mathrm{v}$ času izrednih razmer ustrezno usposobljene in pripravljene. Namen raziskave je bil prevesti in prilagoditi merski instrument Lestvica profesionalnih kompetenc medicinskih sester $v$ izrednih razmerah (LPKMS-IR) ter oceniti njegove psihometrične lastnosti. Metode: Uporabljen je bil kvantitativni metodološki raziskovalni dizajn. Lestvica je bila testirana na priložnostnem vzorcu 118 medicinskih sester. V trifaznem procesu prilagoditve in validacije se je poleg vsebinske skladnosti preverjalo notranjo konsistentnost, stabilnost in povezanost spremenljivk ter faktorsko strukturo.

Rezultati: Faktorska analiza je podala model s tremi faktorji, pri čemer prvi faktor Temeljne kompetence medicinskih sester v izrednih razmerah pojasni 36,53 \% celotne variance. Rezultati kažejo tudi zelo visoko povezanost med faktorji $(p<0,001)$ in stopnjo zanesljivosti pri celotni lestvici LPKMS-IR (Cronbach $\alpha=$ $0,937)$.

Diskusija in zaključek: Rezultati potrjujejo, da je slovenska različica lestvice LPKMS-IR veljaven in zanesljiv merski instrument. Ob pomanjkanju ustreznih merskih instrumentov omogoča identifikacijo kompetenc medicinskih sester v izrednih razmerah ter nekatere okoliščine njihovih vlog. Ugotovitve nakazujejo tudi potrebo po nekaterih spremembah izobraževanja za zdravstveno nego in ciljanem raziskovanju tistih skupin $\mathrm{v}$ zdravstveni negi, ki se po pričakovanjih pogosteje srečujejo z izrednimi situacijami.

\footnotetext{
ABSTRACT

Introduction: In order to deal with the changed roles successfully, confidently and effectively, and to be able to ensure appropriate assistance to those affected during the state of emergency, nurses should be properly trained and prepared. The purpose of the study was to translate, adapt, and evaluate the psychometric properties of the Disaster Nursing Core Competencies Scale (DNCC-Scale).

Methods: A quantitative methodological research design was used. The scale was tested on a convenience sample of 118 nurses. In addition to content compliance, internal consistency, stability and correlation of variables and factor structure were also evaluated in the three-phase process of adaptation and validation.

Results: Factor analysis provided a three-factor model with the first factor Core Competencies of Nurses in Emergencies explaining $36.53 \%$ of the total variance. The results also show a very high correlation between factors $(p<0.001)$ and high reliability of the overall scale (Cronbach $\alpha=0.937)$.

Discussion and conclusion: The results have confirmed that the Slovenian version of the DNCC-Scale is a valid and reliable measuring instrument. In the absence of appropriate measurement instruments, it enables an identification of the core competencies of nurses in disaster management and some other circumstances of their roles. The findings also suggest the need for the implementation of some changes in nursing study programs and for more focused studies on those groups in nursing who are expected to encounter disaster events more frequently.
} 


\section{Uvod}

Konec preteklega leta, natančneje 31. decembra 2019, so kitajske oblasti Svetovni zdravstveni organizaciji (SZO) poročale o nekaj primerih pacientov $\mathrm{s}$ pljučnico neznane etiologije $\mathrm{v}$ mestu Vuhan (provinca Hubei). Teden dni pozneje je kitajskim oblastem uspelo identificirati in izolirati povzročitelja - povsem nov koronavirus, pozneje poimenovan SARS-CoV-2 (COVID-19). Zaradi izjemno velike stopnje kužnosti se je bolezen pričela nezadržno širiti po vsem svetu. 31. januarja $2020 \mathrm{iz}$ Italije poročajo o prvih dveh primerih. V Sloveniji je bil 4. marca 2020 potrjen prvi primer s COVID-19. SZO je 11. marca 2020 razglasila pandemijo in dan pozneje vlada Republike Slovenije epidemijo, s čimer je bil aktiviran državni načrt. 13. marca 2020 je Evropa postala epicenter pandemije (Allison, 2020; European Centre for Disease Prevention and Control, 2020; Nacionalni inštitut za javno zdravje, 2020). Od 31. decembra 2019 do 26. aprila 2020 je bilo v svetu identificiranih 2.844.712 obolelih za COVID-19, od tega 201.315 umrlih (European Centre for Disease Prevention and Control, 2020). V Sloveniji je bilo do 12. maja 2020 pozitivnih 1.463 oseb (skupno število testiranih je bilo takrat 65.694), od tega so 103 umrli, a trenutne številke kažejo na umirjanje epidemije (Urad vlade Republike Slovenije za komuniciranje, 2020).

Izredne razmere obdajajo posebne okoliščine; upravljanje $\mathrm{z}$ njimi zahteva posebno znanje ter sodelovanje vseh poklicnih skupin, vključenih v zaščito in reševanje. Izredne razmere, $v$ katerih so se znašle medicinske sestre pri nas in $\mathrm{v}$ svetu, predstavljajo pomemben izziv tudi $\mathrm{z}$ vidika njihove profesionalne vloge. Medicinske sestre kot najštevilčnejša skupina zdravstvenih delavcev igrajo ključno, čeprav morda včasih manj opazno vlogo pri odzivanju in ukrepanju v času izrednih razmer. $Z$ vidika delovanja zdravstvenih timov v takšnih razmerah je treba upoštevati, da so medicinske sestre običajno prve, ki se srečajo s pacienti. Tudi sicer so bile medicinske sestre skozi zgodovino raznolikih izrednih razmer pomemben element $\mathrm{v}$ vseh fazah poteka, tj. preprečevanja, pripravljenosti, odzivanja in okrevanja (Al Thobaity, et al., 2016; Al Thobaity, et al., 2017; Hugelius \& Adolfsson, 2019; Wang, et al., 2020).

Zaradi narave dela $\mathrm{v}$ zdravstveni negi prevzemajo medicinske sestre $\mathrm{v}$ času izrednih razmer nove, spremenjene oziroma razširjene vloge, kot so koordinator aktivnosti $\mathrm{v}$ žariščih izrednih razmer, informator, čustvena in psihološka podpora, zagotavljanje prve in nujne medicinske pomoči, triažiranje ipd. (Li, et al., 2016; Al Thobaity, et al., 2017; Pourvakhshoori, et al., 2017). Obenem pa so te vloge postavljene $\mathrm{v}$ drugačen kontekst od običajnega: spremenjeni organizacijski mehanizmi, težavni delovni pogoji, akutni zdravstveni problemi in množična obolevnost, velika psihična obremenitev in hitro spreminjajoči se vidik skrbi, ki se na začetku npr. usmerja $\mathrm{v}$ reševanje življenja in pozneje $\mathrm{v}$ preprečevanje širjenja okužbe ( $\mathrm{Li}$, et al., 2016). Za uspešno, samozavestno in učinkovito spoprijemanje $s$ temi vlogami in zagotavljanje ustrezne pomoči prizadetim morajo biti tudi medicinske sestre ustrezno usposobljene in pripravljene (Al Thobaity, et al., 2017). Pretekle izkušnje izrednih razmer so namreč pokazale, da visoka stopnja usposobljenosti medicinskih sester pomembno prispeva $\mathrm{k}$ boljšemu upravljanju $\mathrm{z}$ izrednimi razmerami, zmanjšani smrtnosti, stroškovni učinkovitosti in drugim pozitivnim izidom (Li, et al., 2016; Nilsson, et al., 2016; Park \& Kim, 2017; Pourvakhshoori, et al., 2017; Said \& Chiang, 2020).

Kljub temu da je bila že leta 2009 s strani Mednarodnega sveta medicinskih sester (ang. International Council of Nursing [ICN]) in SZO prepoznana pomembnost dobre pripravljenosti medicinskih sester na izredne razmere, na podlagi katere je bil izoblikovan kompetenčni okvir za delo medicinskih sester v izrednih razmerah (ang. ICN Framework of Disaster Nursing Competencies), do danes v Sloveniji nismo zasledili raziskave, v kateri bi raziskovalci preučevali kompetence medicinskih sester glede na omenjeno. Kompetenčni okvir se usmerja v štiri faze poteka izrednih razmer (preprečevanje, pripravljenost, odzivanje in okrevanje), znotraj katerih je bilo v desetih domenah prepoznanih 130 kompetenc medicinskih sester ( $\mathrm{Al}$ Thobaity, et al., 2016; Li, et al., 2016; Al Thobaity, et al., 2017; Park \& Kim, 2017).

Deset let po razvoju tega kompetenčnega okvira je ICN (2019) v preteklem letu objavil drugo, spremenjeno različico kompetenc medicinskih sester v izrednih razmerah. Slednje je ICN vezal na tri ravni usposobljenosti medicinske sestre: (1) vsaka medicinska sestra; (2) medicinska sestra s specialnimi znanji, ki je odgovorna oseba za koordinacijo zdravstvene nege $\mathrm{v}$ instituciji, organizaciji ali sistemu; (3) medicinska sestra, ki je dosegla prvo in drugo raven ter je usposobljena za delo $\mathrm{v}$ različnih žariščih izrednih razmer in je zaradi tega lahko hitro mobilizirana (International Council of Nurses, 2019).

Delovanje medicinskih sester $\mathrm{v}$ izrednih razmerah je odvisno tudi od znanja in veščin s tega področja, ki povečujejo njihovo pripravljenost in občutek opolnomočenja za delo v takšnih razmerah. Nekatere raziskave (Al Thobaity, et al., 2017; Park \& Kim, 2017) namreč kažejo, da dosedanja organiziranost izobraževanj in usposabljanj ne zagotavlja ustrezne usposobljenosti.

Razvoj veljavnega psihometričnega pripomočka je pomemben za preverjanje oziroma samoocenjevanje profesionalnih kompetenc medicinskih sester. Ker na področju izrednih razmer v Sloveniji ni bilo razvitega tovrstnega instrumentarija, je bila $\mathrm{v}$ tej situaciji validacija tujega vprašalnika logična rešitev. Poleg tega je primernih instrumentov za merjenje kompetenc medicinskih sester v izrednih razmerah tudi drugod 
po svetu le peščica (Al Thobaity, et al., 2016), kar otežuje dejansko oceno usposobljenosti. Zato je prvi korak razvoja novega ali preverjanja merskih lastnosti obstoječega testa ali vprašalnika analiza merskih lastnosti posameznih postavk na podlagi psihometričnih testov (Vidmar \& Jakovljević, 2020).

\section{Namen in cilji}

Namen raziskave je bil prevesti in prilagoditi merski instrument Lestvica profesionalnih kompetenc medicinskih sester $\mathrm{v}$ izrednih razmerah (LPKMSIR) ter oceniti njegove psihometrične lastnosti $\mathrm{v}$ času, ko je občutljivost za te kompetence najvišja. Cilj raziskave je bil ponuditi ustrezen merski instrument za ugotavljanje kompetenc medicinskih sester $\mathrm{v}$ času izrednih razmer ter $s$ tem omogočiti nadaljnje raziskovanje tega področja.

\section{Metode}

Psihometrična raziskava je bila del večje kvantitativne raziskave o temeljnih profesionalnih kompetencah medicinskih sester $\mathrm{v}$ izrednih razmerah. Za preverjanje veljavnosti in zanesljivosti lestvice je bil uporabljen kvantitativni metodološki raziskovalni dizajn. V raziskavi so bili uporabljeni različni psihometrični testi za preverjanje veljavnosti lestvice, njene vsebine in konstrukcije ter zanesljivosti lestvice v smislu stabilnosti in notranje konsistentnosti.

\section{Opis instrumenta}

Merski instrument Lestvica profesionalnih kompetenc medicinskih sester $\mathrm{v}$ izrednih razmerah (LPKMS-IR) (ang. Disaster Nursing Core Competencies Scale) je bil razvit na podlagi pregleda literature ter na dosedanjih raziskavah in kompetenčnem okviru ICN iz leta 2009, pri čemer je prestal natančen proces validacije (Al Thobaity, et al., 2016). Izvirni vprašalnik in dovoljenje za njegovo uporabo $\mathrm{v}$ raziskovalne namene smo pridobili pri glavnem avtorju. Celoten vprašalnik je sestavljen iz štirih delov: (i) Demografski in drugi podatki udeležencev; (ii) Vloge medicinskih sester pri upravljanju v izrednih razmerah (5 trditev) (Cronbach $\alpha=0,97)$; (iii) Temeljne kompetence medicinskih sester $\mathrm{v}$ izrednih razmerah (30 trditev) (Cronbach $\alpha=0,92$ ) in (iv) Ovire pri razvijanju zdravstvene nege v izrednih razmerah ( 8 trditev) (Cronbach $\alpha=0,97$ ) (Al Thobaity, et al., 2016).

Predlagana lestvica naj bi zagotovila merjenje temeljnih profesionalnih kompetenc medicinskih sester $\mathrm{v}$ izrednih razmerah, njihovo vlogo in ovire, $s$ katerimi se pri tem srečujejo. Ocenjevanje lestvice LPKMS-IR temelji na desetstopenjski Likertovi lestvici, ki smo jo za potrebe naše raziskave omejili na sedem stopenj. Veliko se razpravlja o tem, koliko stopenj je za tovrstno raziskovanje najbolj smiselnih.
Dillman in sodelavci (2014) priporočajo uporabo samo štiri- ali petstopenjske lestvice, medtem ko Fink (2002) priporoča od pet- do sedem-stopenjske lestvice. Foddy (1993) sklepa, da je za merjenje veljavnosti in zanesljivosti lestvic potrebna najmanj sedemstopenjska Likertova lestvica. Prav tako se zdi, da je slednja primerna za elektronsko razpošiljanje vprašalnikov (Finstad, 2010). Za potrebe izvirne različice vprašalnika so vzorec sestavljale medicinske sestre, zaposlene na urgentnih oddelkih dveh bolnišnic v Savdski Arabiji. Uporabljen je bil nenaključen, namenski vzorec. Skupaj so razdelili 200 vprašalnikov, v vsako bolnišnico po 100 . Vrnjenih je bilo 139 ali $69,5 \%$ (Al Thobaity, et al., 2016).

\section{Preverjanje veljavnosti instrumenta}

Proces prevajanja lestvice običajno velja za prvi korak preverjanja njene veljavnosti. Lestvica je bila prevedena $\mathrm{z}$ uporabo metode vzvratnega prevoda (ang. back translation) (Behling \& Law, 2000) najprej $\mathrm{v}$ slovenski in nato nazaj $\mathrm{v}$ angleški jezik. Prevod smo nato primerjali $\mathrm{z}$ izvirnim besedilom ter na ta način ugotavljali morebitne razlike $\mathrm{v}$ besedilih $\mathrm{v}$ smislu ustreznosti zapisov. V drugem koraku je bila izvedena vsebinska veljavnost $\mathrm{z}$ namenom ugotoviti, ali je vsebina lestvice primerna za ciljno populacijo (Basham, et al., 2009). Posledično smo za vsebinsko veljavnost slovenske različice lestvice izvedli pilotno raziskavo. Deset diplomiranih medicinskih sester, ki je lestvico v tem delu ocenjevalo, je imelo v vprašalniku ob vsaki trditvi na razpolago tudi prostor, namenjen pisanju komentarjev, povezanih $\mathrm{z}$ razumljivostjo izrazov, konceptov, ali postavljanju vprašanj.

$\mathrm{Za}$ potrebe konstruktne veljavnosti smo uporabili konfirmatorno faktorsko analizo (ang. Confirmatory factor analysis, KFA) (Basham, et al., 2009). Namen konstruktne veljavnosti je preveriti, ali lestvica meri tisto, kar želimo meriti, oziroma nam prinaša prav tiste podatke, ki jih želimo dobiti, ter ali spremenljivke statistično pomembno korelirajo med seboj. Izvirna različica vprašalnika je s pomočjo konfirmatorne faktorske analize potrdila smiselnost treh faktorjev, na podlagi katerih so sestavljeni tudi trije deli izvirnega vprašalnika (Al Thobaity, et al., 2016). Primernost podatkov za faktorsko analizo je bila preverjena $s$ pomočjo Kaiser-Meyer-Olkinovega (KMO) kazalca in Bartlettovega testa sferičnosti. Vzorec je primerne velikosti, če je KMO vsaj 0,5 (Field, 2013). Čeprav ni univerzalnega dogovora o velikosti vzorca, ki bi bil primeren za faktorsko analizo, je treba upoštevati, da je minimalno število vsaj 100 ali trikratnik števila vseh trditev $\left(3^{\star} 43=129\right)$ (Mundfrom, et al., 2005). Če Bartlettov test sferičnosti ne pokaže stopnje statistične značilnosti $(p<0,05)$, pomeni, da korelacijska matrika nima statistično značilnih povezav oziroma da spremenljivke ne korelirajo med seboj. Pri analizi podatkov smo upoštevali le tiste spremenljivke, ki 
so imele lastno vrednost komunalitet (delež skupne variance v spremenljivki) višjo od 0,4 (Field, 2013).

\section{Preverjanje zanesljivosti instrumenta}

Preverjanje zanesljivosti lestvice LPKMS-IR je bilo izvedeno na podlagi analize notranje konsistentnosti in stabilnosti na vzorcu 118 diplomiranih medicinskih sester, ki so sodelovale $\mathrm{v}$ zaključni fazi te validacijske raziskave. Zanesljivost in notranjo konsistenco lestvice znotraj vsakega faktorja smo ocenili s Cronbachovim koeficientom alfa (Cronbach $\alpha$ ). Za mejno vrednost Cronbach a smo upoštevali vrednost 0,60 , ki velja za slabo, vendar še sprejemljivo (Field, 2013). Naslednji korak je bila ocena zanesljivosti po metodi enakih polovic za analizo stabilnosti spremenljivk $\mathrm{z}$ uporabo Guttmanovega koeficienta ter koeficienta SpearmanBrown (upoštevana mejna vrednost prav tako 0,60 ). Analiza enakih polovic je alternativna metoda, nekateri navedenima koeficientoma pravijo tudi koeficienta prerokbe, za oceno retestne zanesljivosti oziroma pokazatelj stabilnosti spremenljivk skozi čas (Field, 2013).

\section{Opis vzorca}

Preverjanje veljavnosti in zanesljivosti lestvice LPKMS-IR je potekala na priložnostnem vzorcu medicinskih sester, ki so zaposlene v kliničnem okolju in imajo pridobljeno visokošolsko izobrazbo na prvi ali drugi stopnji študijskega programa zdravstvene nege. $\mathrm{V}$ raziskavi je sodelovalo $99(83,9 \%)$ diplomiranih medicinskih sester / diplomiranih zdravstvenikov in 19 (16,1 \%) magistric / magistrov zdravstvene nege, $\mathrm{s}$ čimer smo dosegli primerno velikost vzorca. Večina jih je ženskega spola $(n=98,83,1 \%)$, starih med 24 in 62 let $(\bar{X}=35,97, s=10,600)$. Anketiranci so zaposleni na primarni ravni zdravstvene dejavnosti $(n=56,47 \%)$, sekundarni ravni zdravstvene dejavnosti $(n=32$, $27,1 \%)$, terciarni ravni zdravstvene dejavnosti $(n=16$, $13,6 \%)$ in v socialnovarstvenih zavodih $(n=12,1,7 \%)$. 23 anketirancev (19,5\%) je zaposlenih na vodilnem ali vodstvenem delovnem mestu. Njihova delovna doba se giblje $1-39$ let $(\bar{x}=13,3, s=12,029)$.

\section{Opis poteka raziskave in obdelave podatkov}

Vprašalnik smo $\mathrm{v}$ zdravstvene institucije oziroma med zaposlene $\mathrm{v} z d$ ravstveni negi razposlali s pomočjo spleta. Anketiranje je bilo prostovoljno in anonimno. $\mathrm{Za}$ izvedbo raziskave smo pridobili ustrezno soglasje. Spletni vprašalnik, ki mu je bilo dodano pojasnilo o namenu in načinu izpolnjevanja, je bilo mogoče izpolniti v odprtokodni aplikaciji za spletno anketiranje 1KA od 21. aprila 2020 do 6. maja 2020. $\mathrm{Ob}$ zaključenem anketiranju so bili hkrati preneseni vsi podatki, kar pomeni, da se podatki nepopolno izpolnjenih anket niso shranili. V postopku zbiranja podatkov je bila ustvarjena podatkovna baza, ki je vključevala odgovore anketirancev brez njihovih imen, priimkov in e-poštnih naslovov, s čimer je bila zagotovljena anonimnost. Zbiranje podatkov, ki je bila izključna odgovornost raziskovalcev, se je odvijalo na uporabniškem računu aplikacije $1 \mathrm{KA}$, zaščitenem $\mathrm{z}$ geslom. Med analizo podatkov so bili podatki dostopni samo glavnim preiskovalcem. Za namene statistične analize so bili podatki nato izvoženi v IBM SPSS, verzija 25.0 (SPSS Inc., Chicago, IL, ZDA). Z uporabo navedenega programa smo za ugotavljanje psihometričnih lastnosti slovenske različice lestvice LPKMS-IR izvedli naslednje statistične analize: Cronbachov koeficient alfa za ugotavljanje notranje konsistentnosti, Guttmanov ter Spearman-Brownov koeficient za analizo stabilnosti spremenljivk, konfirmatorno faktorsko analizo za preverjanje faktorske strukture in Pearsonov koeficient korelacije za ugotavljanje povezanosti med posameznimi spremenljivkami.

\section{Rezultati}

$\mathrm{V}$ raziskavi je sodelovalo 118 medicinskih sester. V nadaljevanju prikazujemo rezultate po fazah validacije Lestvice profesionalnih kompetenc medicinskih sester v izrednih razmerah oziroma lestvice LPKMS-IR.

\section{Prva faza: Prevod lestvice LPKMS-IR (vsebinska veljavnost)}

Vprašalnik je bil najprej preveden iz angleškega v slovenski jezik. Pri oblikovanju začetne slovenske različice vprašalnika sta sodelovala strokovnjaka $s$ preiskovanega področja in kvantitativnih metod raziskovanja, ki sta predlagala nekatere dopolnitve $\mathrm{v}$ povezavi s terminološko ustreznostjo. Sledil je vzvratni prevod, pri čemer je bila slovenska različica vprašalnika prevedena nazaj $\mathrm{v}$ angleški jezik. Obe različici vprašalnika so raziskovalci pregledali na podlagi zdravorazumske veljavnosti (ang. face validity) ter na tej stopnji vnesli določene dopolnitve oziroma popravke. Takšna oblika vprašalnika je bila uporabljena $\mathrm{v}$ pilotni študiji na vzorcu 10 medicinskih sester, zaposlenih $\mathrm{v}$ klinični praksi, da bi preverili tudi razumljivost pripravljene lestvice. Anketiranci so ugotovili, da je bilo vseh 43 trditev v vprašalniku jasno, jedrnato in razumljivo zapisanih. Na podlagi minimalnih korektur besedila - pravopisnih napak - smo oblikovali končno različico slovenske lestvice LPKMS-IR.

\section{Druga faza: Veljavnost lestvice LPKMS-IR (konstrukcijska veljavnost)}

Preverjanje veljavnosti lestvice smo izvedli na podlagi KFA treh veljavnih faktorjev. Analiza odvisnosti med spremenljivkami je pokazala smiselnost uporabe 
faktorske analize, kar potrjujeta Kaiser-MeyerOlkinov kazalec in Bartlettov test sferičnosti $(\mathrm{KMO}=$ 0,856 , Barlettov test sferičnosti $\chi^{2}=4144,89, d f=903$, $p<0,001)$. Iz rezultatov sledi, da je bila vzorčna populacija sprejemljiva.

Pri analizi podatkov smo upoštevali le tiste spremenljivke, ki so imele lastno vrednost komunalitete višjo od 0,4 . Tako smo iz analize izločili spremenljivke, ki si variabilnosti z nobeno drugo spremenljivko niso delile $\mathrm{v}$ zadostni meri, in sicer trditve pod zaporedno številko 12, 23, 42 in 43. Matrika faktorskih uteži (Tabela 1) je pokazala tudi, da so bile - razen trditev, ki smo jih izločili - faktorske obremenitve večje od 0,55 . S faktorskim modelom lahko pojasnimo 56,77 $\%$ variabilnosti. Univariatno normalno porazdelitev indikatorskih spremenljivk smo ugotavljali z analizo

Tabela 1: Matrika faktorskih uteži lestvice LPKMS-IR

Table 1: Factor loading matrix of LPKMS-IR scale

\begin{tabular}{|c|c|c|c|}
\hline \multirow{2}{*}{ Trditve / Statements } & \multicolumn{3}{|c|}{ Faktorji / Factors } \\
\hline & 1 & 2 & 3 \\
\hline ... za spremljanje in delo znotraj vzpostavljenega ... & 0,835 & 1 & 1 \\
\hline ... prepoznati morebitne grožnje $\mathrm{z}$ zdravstvenimi ... & 0,829 & 1 & 1 \\
\hline ... zagotavljati ustrezne rešitve za razreševanje etičnih ... & 0,825 & 1 & 1 \\
\hline ... za razumevanje namena načrta zaščite in reševanja ... & 0,815 & 1 & 1 \\
\hline ... za razumevanje načinov kriznega komuniciranja $\mathrm{v}$... & 0,806 & 1 & l \\
\hline ... za ohranjanje ustreznega znanja s področja delovanja ... & 0,782 & I & 1 \\
\hline ... opisati različne vloge medicinske sestre $\mathrm{v}$ primeru ... & 0,777 & I & 1 \\
\hline ... za sodelovanje v načrtovanju aktivnosti za zadovoljevanje ... & 0,774 & 1 & 1 \\
\hline ... razumeti potek načrta zaščite in reševanja $\mathrm{v}$ izrednih ... & 0,773 & 1 & 1 \\
\hline ... opisati strategije za etično dodeljevanje omejenih resursov ... & 0,769 & 1 & I \\
\hline ... navesti ustrezne korake za zagotavljanje nujne psihološke ... & 0,763 & 1 & 1 \\
\hline ... za triažiranje zdravstvene oskrbe in sočasno obvladovanje ... & 0,747 & 1 & 1 \\
\hline ... upravljanja resursov in potrebščin / zalog, ki so potrebni ... & 0,716 & 1 & 1 \\
\hline ... prepoznati ranljivo populacijo in uskladiti dejavnosti ... & 0,713 & 1 & I \\
\hline ... za sodelovanje pri oblikovanju novih smernic v ... & 0,712 & I & I \\
\hline ... opisati faze ciklov upravljanja v izrednih razmerah ... & 0,707 & 1 & 1 \\
\hline ... zagotavljati sprotne informacije odgovorim v zvezi ... & 0,702 & 1 & 1 \\
\hline ... razviti in prilagajati osebni in družinski načrt ... & 0,700 & / & l \\
\hline ... za razumevanje posameznih elementov načrta ... & 0,698 & 1 & 1 \\
\hline ... uporabe postopkov vodenja evidenc v smeri ... & 0,693 & 1 & 1 \\
\hline ... prepoznati in ukrepati pri pacientih v nekaterih ... & 0,690 & 1 & 1 \\
\hline ... v času izrednih razmer organizirati in izpeljati ... & 0,686 & 1 & I \\
\hline ... za sodelovanje na vajah $\mathrm{v}$ delovnem okolju in ... & 0,656 & 1 & 1 \\
\hline ... za sodelovanje v procesih zagotavljanja ustrezne ... & 0,655 & 1 & 1 \\
\hline ... prepoznati in prenesti pomembne informacije ... & 0,648 & 1 & 1 \\
\hline ....razumeti ustrezno terminologijo, ki se uporablja v ... & 0,623 & 1 & I \\
\hline ... reševanja pacientov in s tem povečati njihovo možnost... & 0,564 & I & I \\
\hline ... ustreznih programov usposabljanja na ... & 1 & 0,840 & 1 \\
\hline ... učinkovitih tečajev oz. možnosti ... & 1 & 0,823 & 1 \\
\hline ... formalnih izobraževanj ... & I & 0,813 & I \\
\hline ... podpore s strani zdravstvene ... & 1 & 0,773 & 1 \\
\hline ... strokovnega osebja za področje ... & I & 0,761 & 1 \\
\hline ... ustreznih instrumentov $\mathrm{za} . .$. & 1 & 0,721 & 1 \\
\hline ... vloge medicinskih sester pri organizaciji ... & 1 & 0,704 & 1 \\
\hline ... raziskav s področja zdravstvene nege ... & 1 & 0,699 & 1 \\
\hline ... pri izobraževanju in usposabljanju ... & 1 & 1 & 0,854 \\
\hline ... pri identifikaciji potreb po izobraževanju ... & 1 & 1 & 0,848 \\
\hline ... sem za aktivacijo lokalnega načrta za ... & 1 & 1 & 0,791 \\
\hline ... pri razvijanju načrtov in politike izrednih ... & 1 & 1 & 0,773 \\
\hline
\end{tabular}

Legenda / Legend: 1 - prvi faktor: Temeline kompetence medicinskih sester v izrednih razmerah / first factor Core competencies of disaster nursing; 2 - drugi faktor: Ovire pri razvijanju zdravstvene nege v izrednih razmerah / second factor Barriers to developing disaster nursing; 3 - tretji faktor: Vloge medicinskih sester pri upravljanju v izrednih razmerah / third factor Nurses' roles in disaster nursing 
Tabela 2: Matrica povezanosti med faktorji lestvice LPKMS-IR

Table 2: Inter-factor correlation matrix of the LPKMS-IR scale

\begin{tabular}{llll}
\hline Faktorji / Factors & $\mathbf{1}$ & $\mathbf{2}$ & $\mathbf{3}$ \\
\hline Temeljne kompetence medicinskih sester v izrednih razmerah & 1 & $0,773^{* *}$ & $0,769^{* *}$ \\
\hline Ovire pri razvijanju zdravstvene nege v izrednih razmerah & $/$ & 1 & $0,683^{* *}$ \\
\hline Vloge medicinskih sester pri upravljanju v izrednih razmerah & $/$ & $/$ & 1 \\
\hline $\begin{array}{l}\text { Legenda / Legend: 1 - prvi faktor / first factor; 2 - drugi faktor / second factor; 3 - tretji faktor / third factor; } \\
\text { pomembna pri stopnji značilnosti 0,01 / correlation is significant at the 0.01 level }\end{array}$ &
\end{tabular}

Tabela 3: Testi zanesljivosti lestvice LPKMS-IR in njenih faktorjev

Table 3: Reliability test for the LPKMS-IR scale and its factors

\begin{tabular}{lllll}
\hline Faktorji / Factors & $\boldsymbol{n}$ & $\begin{array}{l}\text { Cronbach } \boldsymbol{\alpha} \text { koeficient / } \\
\text { Cronbach } \alpha \text { coefficient }\end{array}$ & $\begin{array}{l}\text { Guttman koeficient } \\
\text { enakih polovic / } \\
\text { Guttman split-half } \\
\text { coefficient }\end{array}$ & $\begin{array}{l}\text { Spearman Brown } \\
\text { koeficient / } \\
\text { Spearman Brown } \\
\text { coefficient }\end{array}$ \\
\hline $\begin{array}{l}\text { Temeljne kompetence medicinskih } \\
\text { sester v izrednih razmerah }\end{array}$ & 27 & 0,968 & 0,955 & 0,956 \\
\hline $\begin{array}{l}\text { Ovire pri razvijanju zdravstvene } \\
\text { nege v izrednih razmerah }\end{array}$ & 8 & 0,887 & 0,886 & 0,887 \\
\hline $\begin{array}{l}\text { Vloge medicinskih sester pri } \\
\text { upravljanju v izrednih razmerah }\end{array}$ & 4 & 0,916 & 0,864 & 0,864 \\
\hline $\begin{array}{l}\text { Celotna lestvica LPKMS-IR } \\
\text { Legenda / Legend: } n \text { - število / number }\end{array}$ & 39 & 0,937 & 0,789 & 0,800 \\
\hline
\end{tabular}

vrednosti asimetrije (ang. Skewness) in sploščenosti (ang. Kurtosis). Vse indikatorske spremenljivke so izkazovale vrednosti asimetrije in sploščenosti manjše od 2, kar je za izvedbo KFA sprejemljivo $(-0,349-$ 0,471). Rezultati so pokazali še, da je skladnost preučevanega modela s tremi faktorji (s 39 trditvami) lestvice LPKMS-IR popolnoma ustrezna: vrednost hi-kvadrat testa $\left(\chi^{2}\right)$ za tri faktorje je znašala 107,32 $(47,97-184,30, d f=5, p<0,001)$ in kaže na ustrezno prileganje, RMSEA (ang. Root Mean Square Error of Approximation) pa 0,064 (CI $95 \%=0,25-0,98$ ), kar kaže na zadovoljivo prileganje. Največja lastna vrednost pripada prvemu faktorju in je enaka 15,71 . To pojasni $36,53 \%$ celotne variabilnosti ali celotne razpršenosti podatkov (drugi faktor 5,05, 11,74 \%; tretji faktor 3,66, 8,51 \%). Matriko faktorskih uteži prikazujemo v Tabeli 1.

V okviru preverbe merskega modela smo navedli tudi korelacijske koeficiente med faktorji. Rezultati kažejo na zelo visoko povezanost, iz česar izhaja, da so vse korelacije statistično pomembne, $p<0,001$ (Tabela 2).

\section{Tretjafaza: Preverjanje zanesljivosti instrumenta}

Preizkus zanesljivosti lestvice LPKMS-IR je bil izveden $\mathrm{z}$ uporabo testov zanesljivosti in stabilnosti na vseh treh faktorjih $\mathrm{v}$ vprašalniku. Rezultati so pokazali odlično stopnjo zanesljivosti pri celotni lestvici LPKMS-IR (Cronbach $\alpha=0,937)$ - pri faktorju Temeljne kompetence medicinskih sester v izrednih razmerah (Cronbach $\alpha=0,968$ ) in faktorju Vloge medicinskih sester pri upravljanju v izrednih razmerah (Cronbach $\alpha=0,916)$ - ter dobro stopnjo zanesljivosti pri faktorju Ovire pri razvijanju zdravstvene nege $\mathrm{v}$ izrednih razmerah (Cronbach $\alpha=0,887$ ) (Tabela 3).

Guttmanov koeficient enakih polovic in Spearmanov koeficient stabilnosti smo uporabili za oceno celotne lestvice LPKMS-IR in njenih faktorjev. Test je sprejemljiv, če je vrednost $>0,800$. Za Guttmanov koeficient pa zadostuje že vrednost testa $>0,600$. Rezultati so pokazali, da sta bila oba testa sprejemljiva tako pri celotni lestvici LPKMS-IR kot pri vseh treh faktorjih $(>0,700)$.

\section{Diskusija}

Vsako leto prihaja tako doma kot po svetu do nastanka različnih oblik nesreč, na podlagi katerih se ljudje soočajo $z$ zdravstvenimi, finančnimi, gospodarstvenimi in drugimi oblikami izgube. Medicinske sestre predstavljajo največjo skupino zdravstvenih delavcev in imajo pomembno vlogo pri odzivanju zdravstvenega sistema $\mathrm{v}$ primeru pojava izrednih razmer (Pourvakhshoori, et al., 2017), kakršne predstavlja trenutna pandemija COVID-19, $s$ katero se srečujejo številne države po vsem svetu, vključno s Slovenijo. Čeprav je pojem »zdravstvena nega v izrednih razmerah" (ang. disaster nursing) razmeroma nov in je to področje zdravstvene nege še v zgodnjih fazah razvoja po vsem svetu, tako raziskovalci kot odločevalci in sama stroka priznavajo njen pomen (Al Thobaity, et al., 2016). Nekatere severnoameriške, evropske in vzhodnoazijske države si prizadevajo razvijati temeljne kompetence na področju zdravstvene nege $\mathrm{v}$ izrednih razmerah ter medicinske sestre s pomočjo formalnih in neformalnih 
izobraževalnih programov usposobiti za prenašanje tega znanja $\mathrm{v}$ vsakdanjo klinično prakso (Al Thobaity, et al., 2015; Labrague, et al., 2018; Zhang, et al., 2018; Kalanlar, 2019; Said \& Chiang, 2020). Trenutno obstaja pomanjkanje dobro uveljavljenih orodij za raziskovanje temeljnih kompetenc zaposlenih $\mathrm{v}$ zdravstveni negi $\mathrm{v}$ okviru izrednih razmer, njihove vloge in morebitnih ovir, s katerimi bi se lahko pri tem srečevali (Al Thobaity, et al., 2016). Poleg tega zdravstvena nega $\mathrm{v}$ izrednih razmerah v Sloveniji ni jasno definirana, zato je to področje treba raziskati in vpeljati temeljne kompetence. V obdobju, ko se globalno srečujemo $\mathrm{z}$ izrednimi razmerami, povezanimi s pandemijo COVID-19, smo zato želeli prevesti in prilagoditi merski instrument LPKMSIR in oceniti njegove psihometrične lastnosti, saj je občutljivost do dela na tem področju med zaposlenimi $\mathrm{v}$ zdravstveni negi $\mathrm{v}$ tem času izjemno visoka.

Rezultati kažejo, da je izvirni vprašalnik primeren za slovensko različico. KMO in Bartlettov test sferičnosti sta pokazala, da je izvedba KFA na zbranih podatkih primerna. S pomočjo faktorske analize, ki nam omogoča pojasnitev variance, skupne več spremenljivkam hkrati, smo dobili tri faktorje: (1) Vloge medicinskih sester pri upravljanju v izrednih razmerah; (2) Temeljne kompetence medicinskih sester v izrednih razmerah in (3) Ovire pri razvijanju zdravstvene nege $v$ izrednih razmerah, kar je skladno z izvirnim vprašalnikom (Al Thobaity, et al., 2016). $\mathrm{V}$ slovenski različici vprašalnika smo sicer izločili štiri trditve (tri trditve iz drugega faktorja in eno trditev iz tretjega faktorja), ker si niso delile zadostne variabilnosti $\mathrm{z}$ drugimi trditvami, kar je od začetnih 43 privedlo do 39 trditev. Iz sklopa trditev, ki se je nanašal na temeljne kompetence medicinskih sester v izrednih razmerah, so bile izločene trditve, ki so se navezovale na prepoznavanje vedenjskih motenj pri ljudeh v izrednih razmerah, vodenje in nadzorovanje prostovoljcev, ter naštevanja kratkoročnih in dolgoročnih posledic izpostavljenosti izredni situaciji (drugi faktor). Iz sklopa trditev, ki so se nanašale na ovire pri razvijanju zdravstvene nege $\mathrm{v}$ izrednih razmerah, je bila izločena trditev, ki se je nanašala na redno udeleževanje usposabljanj s področja množičnih nesreč (tretji faktor). Zanesljivost in stabilnost vprašalnika $\mathrm{v}$ celoti in po posameznih faktorjih vprašalnika, iz katerega so bile posamezne trditve izločene, sta se pokazali za izjemno dobri. Veljavnost vprašalnika je bila preverjena na več ravneh. Že pred pričetkom raziskave na vzorcu pilotne študije, s katero smo preverjali razumljivost vprašalnika in vsebinsko veljavnost. Konstruktna veljavnost je bila preverjena s pomočjo korelacijske analize, kjer se je pokazala zelo visoka povezanost med faktorji. Zaključimo lahko, da so psihometrične lastnosti vprašalnika zelo dobre.

Lestvica jasno opredeljuje tri glavne dejavnike, ki so ključni pri postavljanju temeljev izobraževanja medicinskih sester na področju izrednih razmer $\mathrm{v}$
Sloveniji. Prvi faktor je najpomembnejši in se nanaša na temeljne kompetence medicinskih sester. Podatki so razkrili številne ključne kompetence medicinskih sester v primeru izrednih razmer, kot so načrtovanje, komunikacija, etična vprašanja, upravljanje virov, psihološka pripravljenost, oskrba pacienta idr. Pridobljeni rezultati so skladni $\mathrm{z}$ ugotovitvami dosedanjih raziskav, ki poudarjajo ustrezno znanje in spretnosti, ki jih potrebujejo medicinske sestre $\mathrm{v}$ primeru izrednih razmer (Al Thobaity, et al., 2015; Al Thobaity, et al., 2016; Kalanlar, 2019). Validacija vprašalnika je $\mathrm{v}$ tej raziskavi zajela medicinske sestre in diplomirane zdravstvenike iz različnih kliničnih okolij in ravni zdravstvenega varstva, saj so se morala v obstoječi situaciji, povezani s COVID-19, vsa okolja reorganizirati in pripraviti načrte zdravstvene obravnave v primeru izrednih razmer. V prihodnje bi lestvico veljalo testirati na ožje usmerjeni populaciji, kot so zaposleni v nujni medicinski pomoči, saj so ti pri svojem vsakdanjem delu pogosto izpostavljeni izrednim situacijam (npr. množičnim nesrečam). Prav tako je glede na trenutne razmere smiselno specifično testiranje med zaposlenimi $\mathrm{v}$ zdravstveni negi $\mathrm{v}$ socialnovarstvenih zavodih kot tudi testiranje lestvice med zdravstvenimi tehniki.

\section{Zaključek}

Raziskava je pokazala, da ima lestvica LPKMS-IR dobre psihometrične lastnosti ter velja za zanesljiv in veljaven instrument za merjenje profesionalnih kompetenc medicinskih sester v izrednih razmerah. Izobraževalne ustanove, ki izvajajo študij zdravstvene nege, bi morale imeti pomembno vlogo pri usposabljanju in pripravi prihodnjih medicinskih sester na izredne razmere, čeprav je ta izraz za slovenski prostor nov. Upamo, da lahko ta instrument pripomore $\mathrm{k}$ nadaljnjemu raziskovanju tega pomembnega specialnega področja in $s$ tem $\mathrm{k}$ razmisleku o vpeljevanju izraza »izredne razmere " $\mathrm{v}$ zdravstveno nego ter $\mathrm{s}$ tem vpeljavo določenih novih vsebin $\mathrm{v}$ učne programe zdravstvene nege v Sloveniji.

\section{Zahvala / Acknowledgements}

Radi bi se zahvalili vsem zaposlenim v zdravstveni negi, da so si v tem obdobju, ko so bili nadčloveško obremenjeni vzeli čas in izpolnili vprašalnik. Zahvala gre tudi dr. Abdulellah Al Thobaity in dr. Virginiji Plummer za razumevanje in hitro odzivnost pri posredovanju originalnega vprašalnika. / We would like to express our gratitude to all nursing professionals for taking the time to complete the questionnaire during this period of epidemic when they were overwhelmed with work. We would also like to thank Dr Abdulellah Al Thobaity and Dr Virginia Plummer for their understanding and quick response in sharing the original questionnaire. 


\section{Nasprotje interesov / Conflict of interest}

Avtorji izjavljajo, da ni nasprotja interesov. / The authors declare that no conflicts of interest exist.

\section{Financiranje / Funding}

Raziskava ni bila finančno podprta. / The study received no funding.

\section{Etika raziskovanja / Ethical approval}

Raziskavo je odobrila Komisija za znanstvenoraziskovalno delo Fakultete za vede o zdravju Univerze na Primorskem. Raziskava je pripravljena $\mathrm{v}$ skladu z načeli Helsinško-Tokijske deklaracije (World Medical Association, 2013) in v skladu s Kodeksom etike v zdravstveni negi in oskrbi Slovenije (2014). I The study was approved by the Scientific-research committee of the Faculty of Health Sciences University of Primorska. The study was conducted in accordance with the Helsinki-Tokyo Declaration (World Medical Association, 2013) and the Code of Ethics for Nurses and Nurse Assistants of Slovenia (2014).

\section{Prispevek avtorjev / Author contributions}

Avtorji so skupaj zasnovali idejo in načrt raziskave ter raziskavo izvedli. Pri nastanku članka oziroma njegovih sestavnih delov so vsi trije avtorji sodelovali $\mathrm{v}$ enakem obsegu. / The authors jointly conceived the idea and the research plan, and carried out the research. All three authors equally participated in the writing of the article or its chapters.

\section{Literatura}

Al Thobaity, A., Plummer, V., Innes, K. \& Copnell, B., 2015. Perceptions of knowledge of disaster management among military and civilian nurses in Saudi Arabia. Australasian Emergency Nursing Journal, 18(3), pp. 156-164.

https://doi.org/10.1016/j.aenj.2015.03.001

PMid:25864385

Al Thobaity, A., Williams, B. \& Plummer, V., 2016. A new scale for disaster nursing core competencies: development and psychometric testing. Australasian emergency nursing, 19(1), pp. 11-19.

https://doi.org/10.1016/j.aenj.2015.12.001

PMid:26778698

Al Thobaity, A., Plummer, V. \& Williams, B., 2017. What are the most common domains of the core competencies of disaster nursing: a scoping review. International Emergency Nursing, 31, pp. 64-71.

https://doi.org/10.1016/j.ienj.2016.10.003

PMid:28029612; PMCid:PMC7118449
Allison, M., 2020. Timeline of COVID-19 in the News. Available at: http://www.accessmedicinenetwork.com/users/83839-melanie-allison-dnp-msn-rn-acnp-bc/posts/63802-timeline-ofcovid-19-in-the-news [6. 5. 2020].

Basham, R.E., Jordan, C. \& Hoefer, R.A., 2009. Reliability and validity in quantitative measurement. In: B.A. Thyer, ed. The Handbook of social work research methods. 2nd ed. Thousand Oaks: SAGE, pp. 51-64.

https://doi.org/10.4135/9781412986182.n4

Behling, O. \& Law, K., 2000. Translating questionnaires and other research instruments. Thousand Oaks: SAGE.

https://doi.org/10.4135/9781412986373

Dillman, D.A., Smyth, J.D. \& Christian, L.M., 2014. Internet, phone, mail, and mixed-mode surveys: the tailored design method. 4th ed. Available at: https://www.wiley.com/en-si/Internet $\% 2 \mathrm{C}+\mathrm{Ph}$ one $\% 2 \mathrm{C}+$ Mail $\% 2 \mathrm{C}+$ and + Mixed + Mode + Surveys $\% 3 \mathrm{~A}+$ The $+\mathrm{T}$ ailored+Design + Method\%2C +4 th + Edition-p-9781118456149 [6. 5. 2020].

European Centre for Disease Prevention and Control, 2020. Situation update worldwide. Available at: https://www.ecdc. europa.eu/en/geographical-distribution-2019-ncov-cases [6. 5. 2020].

Field, A., 2013. Discovering statistics using SPSS. 3rd ed. Thousand Oaks: SAGE.

Fink, A., 2002. How to ask survey questions. Thousand Oaks: SAGE.

https://doi.org/10.4135/9781412984393

Finstad, K., 2010. Response interpolation and scale sensitivity: evidence against 5-point scales. Journal of Usability Studies, 5(3), pp. 104-110.

Foddy, W.H., 1993. Constructing questions for interviews and questionnaires: theory and practice in social research. New York: Cambridge University Press, p. 228.

https://doi.org/10.1017/CBO9780511518201

Hugelius, K. \& Adolfsson, A., 2019. The HOPE model for disaster nursing: a systematic literature review. International Emergency Nursing, 45, pp. 1-9.

https://doi.org/10.1016/j.ienj.2019.03.007

PMid:31005569

International Council of Nurses, 2019. Core competencies in disaster nursing version 2.0. Geneva: International Council of Nurses. Available at: https://www.icn.ch/sites/default/files/ inline-files/ICN Disaster-Comp-Report WEB.pdf [5. 5. 2020].

Kalanlar, B., 2019. The Challenges and opportunities in disaster nursing education in Turkey. Journal of Trauma Nursing, 26(3), pp. 164-170.

https://doi.org/10.1097/JTN.0000000000000417

PMid:31483775 
Kodeks etike $v$ zdravstveni negi in oskrbi Slovenije, Uradni list RS, št. 71/14.

Labrague, L.J., Hammad, K., Gloe, D.S., McEnroe-Petitte, D.M., Fronda, D.C., Obeidat, R.N., et al., 2018. Disaster preparedness among nurses: a systematic review of literature. International Nursing Review, 65(1), pp. 41-53.

https://doi.org/10.1111/inr.12369

PMid:28295314

Li, S.-M., Li, X.-R., Yang, D. \& Xu, N.-W., 2016. Research progress in disaster nursing competency framework of nurses in China. Chinese Nursing Research, 3(4), pp. 154-157.

https://doi.org/10.1016/j.cnre.2016.11.003

Mundfrom, D.J., Shaw, D.G. \& Ke, T.L., 2005. Minimum sample size recommendations for conducting factor analyses. International Journal of Testing, 5(2), pp.159-168.

https://doi.org/10.1207/s15327574ijt0502 4

Nacionalni inštitut za javno zdravje, 2020. Koronavirus (SARSCoV-2): ključne informacije. Available at: https://www.nijz.si/sl/ koronavirus-2019-ncov [5. 5. 2020].

Nilsson, J., Johansson, E., Carlsson, M., Florin, J., Leksell, J., Lepp, M., et al., 2016. Disaster nursing: self-reported competence of nursing students and registered nurses, with focus on their readiness to manage violence, serious events and disasters. Nurse Education in Practice, 17, pp. 102-108.

https://doi.org/10.1016/j.nepr.2015.09.012

PMid:26776502

Park, H.-Y. \& Kim, J.-S., 2017. Factors influencing disaster nursing core competencies of emergency nurses. Applied nursing research, 37, pp. 1-5.

https://doi.org/10.1016/j.apnr.2017.06.004

PMid:28985913; PMCid:PMC7135655
Pourvakhshoori, N., Norouzi, K., Ahmadi, F., Hosseini, M. \& Khankeh, H., 2017. Nursing in disasters: a review of existing models. International Emergency Nursing, 31, pp. 58-63.

https://doi.org/10.1016/j.ienj.2016.06.004

PMid:27423385

Said, N.B. \& Chiang, V.C.L., 2020. The knowledge, skill competencies, and psychological preparedness of nurses for disasters: a systematic review. International Emergency Nursing, 48, art. ID100806.

https://doi.org/10.1016/j.ienj.2019.100806

PMid:31685363

Urad vlade Republike Slovenije za komuniciranje, 2020. Aktualni podatki o epidemiji Covid-19 v Sloveniji. Available at: https:// www.gov.si/teme/koronavirus/aktualni-podatki/ [4. 5. 2020]

Vidmar, G., \& Jakovljević, M., 2020. Psihometrične lastnosti ocenjevalnih instrumentov. Available at: https://www.dlib.si/ details/URN:NBN:SI:DOC-XB7NJOQR [23. 5. 2020].

Wang, J., Li, C., Zou, S., Chen, H., Xiang, J., Hu, Y., et al., 2020. Psychometric evaluation of undergraduate student nurses' learning perceived needs in disaster nursing: two crosssectional studies. Nurse Education Today, 84, art. ID104208.

https://doi.org/10.1016/j.nedt.2019.104208

PMid:31706206

World Medical Association, 2013. World Medical Association Declaration of Helsinki: ethical principles for medical research involving human subjects. Journal of American Medical Association, 310(20), pp. 2191-2194. https://doi.org/10.1001/jama.2013.281053 PMid:24141714.

Zhang, Y.-Y., Zhu, L.-L., Sheng, Y., Li, X.-H., Xu, X.-H. \& Wang, Q.-Y., 2018. Disaster nursing development in China and other countries: a bibliometric study. Journal of Nursing Scholarship, 50(5), pp. 567-576.

https://doi.org/10.1111/jnu.12401

PMid:29998630

Citirajte kot / Cite as:

Prosen, M., Ličen, S. \& Karnjuš, I., 2020. Prilagoditev in psihometrična validacija Lestvice profesionalnih kompetenc medicinskih sester v izrednih razmerah v času epidemije SARS-CoV-2 (COVID-19) v Sloveniji. Obzornik zdravstvene nege, 54(2), $113-121$. https://doi.org/10.14528/snr.2020.54.2.3037 